\title{
Peningkatan Kapasitas dan Manajemen Keuangan Industri Kerupuk Balok Melalui Program Kemitraan Masyarakat di Desa Bukit Peninjauan II Kecamatan Sukaraja Kabupaten Seluma, Bengkulu
}

\author{
Hesti Nuraini ${ }^{1}$, Evi Andriani ${ }^{2}$, Dewi Suranti ${ }^{2}$ \\ 1,2 Universitas Dehasen Bengkulu
}

\begin{tabular}{l} 
Article History \\
\hline Received 15.08.2019 \\
Received in revised form \\
06.10.2019 \\
Accepted 03.12.2019 \\
Available online 16.12.2019
\end{tabular}

\begin{abstract}
CAPACITY BUILDING AND FINANCIAL MANAGEMENT OF THE KERUPUK BALOK INDUSTRY THROUGH A COMMUNITY PARTNERSHIP PROGRAM IN BUKIT PENINJAUAN II VILLAGE, SUKARAJA DISTRICT, SELUMA DISTRICT, BENGKULU. Bukit Peninjau II Village, Sukaraja Subdistrict, Seluma Regency, has very good potential for the development of small industries, especially home industries in the food sector. One of the small industries in Bukit Peninjauan II Village is the block cracker processing industry which was started in 1995 and currently has 8 business units, including the Usaha Maju and the Raos Echo Community. The team together with partners agreed on several issues faced by partners, including the lack of knowledge (soft skills) and skills mastered by partners regarding product diversification technology, packaging techniques, production equipment and knowledge about financial management. The aim of the Community Partnership Program is to improve partners' skills in the field of product diversification, improvement of packaging and labeling techniques, application of drying system mechanization technology, and increasing partner knowledge in the field of financial management of small industries. The results of the activity show that the product of processed cracker diversification has been formed in the Usaha Maju and the Raos Echo Community, with 3 variants namely original, spinach and carrots crackers. Furthermore, improvements have also been made to the quality of packaging and labeling, through training and providing assistance with labeling equipment. To overcome the problem of drying which has so far been using sunlight, the team provided cabinet drying assistance to the two partners.
\end{abstract}

KEYWORDS: Carrots, Diversification, Kerupuk Balok, Spinach.

This is an open access article distributed under the terms of the Creative Commons Attribution 4.0 International License, which permits unrestricted use, distribution, and reproduction in any medium, provided the original work is properly cited. (c) 2019 Hesti Nuraini, Evi Andriani, Dewi Suranti.

\footnotetext{
${ }^{1}$ Corresponding author: Universitas Dehasen Bengkulu. Jl. Meranti No.32, Sawah Lebar, Kec. Ratu Agung, Kota Bengkulu, Bengkulu 38228
} Indonesia. Email: hestinuraini@unived.ac.id 


\section{PENDAHULUAN}

Perkembangan industri kecil dan menengah di Indonesia telah mengalami peningkatan yang cukup signifikan. Hal ini tidak luput dari peran serta pemerintah daerah maupun pusat yang terus menerus melakukan pembinaan dan bantuan lainnya. Industri pengolahan adalah suatu kegiatan ekonomi yang melakukan kegiatan mengubah suatu barang dasar secara mekanis, kimia, atau dengan tangan sehingga menjadi barang jadi/setengah jadi, dan atau barang yang kurang nilainya menjadi barang yang lebih tinggi nilainya, dan sifatnya lebih dekat kepada pemakai akhir (Rahmana, Iriani, \& Oktarina, 2012). Termasuk dalam kegiatan ini adalah jasa industri/makloon dan pekerjaan perakitan (assembling). Lebih lanjut, Dinas Kesehatan (2017) menyebutkan bahwa industri rumah tangga pangan adalah perusahaan pangan yang memiliki tempat usaha di tempat tinggal dengan peralatan pengolahan pangan yang manual hingga semi otomatis.

Desa Bukit Peninjauan II adalah desa yang terletak di wilayah Kecamatan Sukaraja Kabupaten Seluma Provinsi Bengkulu dengan jarak kurang lebih $25 \mathrm{~km}$ dari Kota Bengkulu. Dilihat dari sumber daya yang ada, Desa Bukit Peninjauan II memiliki potensi yang cukup baik untuk pengembangan industri kecil, khususnya industri rumah tangga di bidang pangan. Namun, hal tersebut belum bisa diupayakan secara optimal, mengingat ketatnya persaingan di era globalisasi. Salah satu industri kecil yang ada di Desa Bukit Peninjauan II adalah industri pengolahan kerupuk balok. Industri pengolahan kerupuk balok dirintis oleh salah seorang warga desa pada tahun 1995. Seiring dengan kemajuan ekonomi, usaha ini mulai dikembangkan oleh beberapa orang, sehingga saat ini telah terdapat 8 usaha pengolahan kerupuk balok di Desa Bukit Peninjauan II (Profil Desa Bukit Peninjauan II, 2017). Hasil survei pendahuluan yang telah tim pengabdi lakukan, menunjukkan bahwa kemajuan usaha pengolahan kerupuk balok di Desa Bukit Peninjauan II relatif kurang. Hal ini disebabkan beberapa faktor antara lain kurangnya minat konsumen terhadap produk kerupuk balok yang mulai terkalahkan oleh produkproduk pangan lain yang lebih modern. Produk kerupuk balok yang dihasilkan ke delapan industri di wilayah Desa Bukit Peninjauan II masih bersifat monoton dari tahun ke tahun dengan penampilan dan rasa yang kurang menarik, tanpa dilakukan proses pengemasan dan labeling yang memadai. Selama ini, kerupuk balok hasil olahan masyarakat Desa Bukit Peninjauan II dijual tanpa varian rasa (original) dengan kemasan plastik kecil yang dilekatkan menggunakan api lilin. Sistem labelling yang digunakan pun masih belum sesuai standar, yakni dengan dimasukkan ke dalam kemasan sehingga bersinggungan langsung dengan produk, yang memungkinkan kontaminasi tinta cetak label ke dalam produk kerupuk. Selain itu, informasi yang ditampilkan dalam label pun masih sangat minim.

Melihat permasalahan tersebut, tim pengabdi tertarik untuk membantu membenahi sistem produksi dan manajemen industri kerupuk balok di Desa Bukit Peninjauan II dengan cara diversifikasi produk, kemasan, labelling, legalitas industri (P-IRT) serta teknik pengeringan menggunakan alat pengering. Dengan peningkatan kualitas, diversifikasi produk, teknologi pengolahan (pengeringan), serta legalitas usaha, produk ini akan menjadi lebih bernilai ekonomi tinggi dan layak untuk dikembangkan serta memungkinkan untuk perluasan area pemasaran. Oleh karena itu, tim pengabdi bersamasama mitra mengidentifikasi bahwa perlu dilakukannya peningkatan soft skill dan ketrampilan bagi para pengusaha pengolahan kerupuk balok di Desa Bukit Peninjauan II, yang bisa dilakukan melalui pendidikan, pelatihan dan aplikasi dalam program 
Pengabdian kepada Masyarakat. Saat ini, terdapat 8 (delapan) industri pengolahan kerupuk balok di Desa Bukit Peninjauan II, tim pengabdi mengambil 2 industri, yaitu Kelompok Raos Echo dan Kelompok Usaha Maju, sebagai mitra kegiatan Pengabdian kepada Masyarakat melalui Program Kemitraan Masyarakat (PKM), dengan pertimbangan selain lokasinya yang relatif mudah dijangkau, stabilitas produksi di kedua industri ini cukup memadai.

Dilihat dari potensi pasar, sebenarnya minat konsumen terhadap produk kerupuk balok tersebut cukup tinggi, sehingga masih sangat memungkinkan untuk dilakukan pengembangan usaha. Beberapa kendala yang dihadapi pemilik usaha kerupuk balok di Desa Bukit Peninjauan II di antaranya adalah belum terdaftarnya usaha mereka di Dinas Kesehatan Kabupaten Seluma, melalui izin P-IRT (Produk Industri Rumah Tangga) dan kendala proses pengeringan yang masih sangat terikat dengan cuaca karena tergantung pada sinar matahari. Hasil wawancara tim tim pengabdi dengan pemilik industri mengungkapkan bahwa, tertundanya proses pengeringan karena cuaca yang tidak mendukung, sangat berpengaruh terhadap mutu kerupuk yang dihasilkan, khususnya pada warna (agak kehitaman) dan teksturnya. Risiko terbesar lainnya adalah, terjadinya gagal produk jika proses pengeringan tidak berjalan dengan baik, sehingga harus dibuang atau dijadikan makanan ternak.

Sebagai mitra kegiatan Pengabdian kepada Masyarakat melalui Program Kemitraan Masyarakat (PKM), tim pengabdi mengambil 2 kelompok, yaitu Kelompok Raos Echo dan Kelompok Usaha Maju, dengan pertimbangan selain lokasinya yang relatif mudah dijangkau, stabilitas produksi di kedua industri ini cukup memadai.

Berdasarkan analisis situasi dan survei yang telah dilakukan, tim pengabdi bersamasama mitra menyepakati beberapa persoalan yang dihadapi oleh mitra, antara lain:

1) Perlunya pengetahuan (soft skill) dan ketrampilan yang dikuasai oleh mitra mengenai teknologi pengolahan, diversifikasi dan pengemasan produk kerupuk balok yang dihasilkan.

2) Peralatan produksi dan teknologi mekanisasi, khususnya proses pengeringan yang masih mengandalkan sinar matahari, sehingga stabilitas kualitas produk kerupuk balok kurang terjaga.

3) Pengemasan masih dilakukan dengan cara tradisional yakni dengan menggunakan plastik kecil yang dilekatkan menggunakan api lilin, sehingga tampak seperti produk inferior.

4) Belum adanya legalitas industri (P-IRT) yang berakibat pada terbatasnya jangkauan pemasaran.

5) Sistem promosi dan manajemen keuangan yang belum optimal.

Lebih jelas, produk kerupuk balok dan metode pengeringan yang dilakukan oleh Kelompok Usaha Maju dan Raos Echo, ditampilkan pada Gambar 1. 


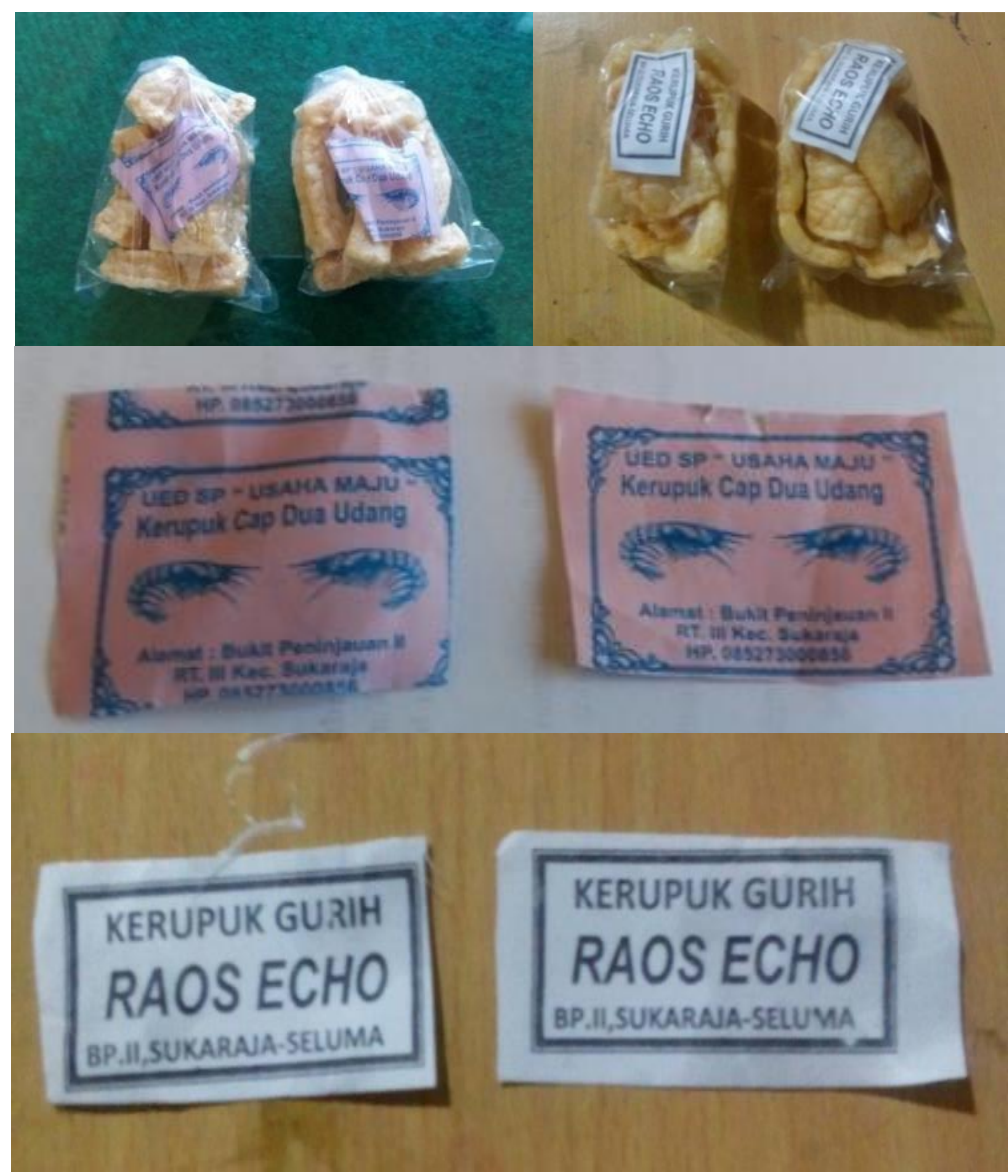

Gambar 1. Tampilan Fisik Produk Kerupuk Balok Kelompok Raos Echo dan Kelompok Usaha Maju

\section{METODE PELAKSANAAN}

Kegiatan pengabdian kepada masyarakat ini dilakukan meliputi sosialisasi dan pelatihan diversifikasi produk kerupuk balok, aplikasi teknologi pengemasan dan labeling yang baik, aplikasi teknologi pengeringan hingga pengurusan perizinan Produk Industri Rumah Tangga (P-IRT), serta pelatihan manajemen keuangan dan strategi pemasaran. Secara rinci tahapan kegiatan yang akan dilakukan meliputi:

\section{Tahap Persiapan}

Tahap persiapan yang dilakukan adalah:

1) Survei, pemantapan dan penentuan lokasi, sasaran serta penentuan permasalahan yang dihadapi oleh mitra;

2) Evaluasi permasalahan dan penentuan solusi yang ditawarkan dan disepakati bersama mitra;

3) Penyusunan materi dan kelengkapan kegiatan. 


\section{Tahap Pelaksanaan}

Tahap pelaksanaan diklat dan penyuluhan, meliputi:

1) Teknologi diversifikasi produk kerupuk balok, dengan varian bahan, yaitu kerupuk balok bayam, kerupuk balok wortel dan kerupuk balok original;

2) Perancangan desain kemasan kerupuk balok dan pelatihan labeling yang sesuai dengan standar minimal kemasan produk pangan;

3) Pemberian bantuan berupa peralatan pengolahan untuk mendukung proses pengolahan yang lebih efektif dan optimal, khususnya aplikasi mekanisasi alat pengering kabinet, sehingga proses produksi tidak terhambat dengan adanya cuaca buruk;

4) Pelatihan manajemen keuangan dan strategi pemasaran untuk industri kecil.

\section{Pendekatan}

Untuk melaksanakan kegiatan tersebut digunakan beberapa metode pelatihan yaitu:

1) Metode ceramah: metode ini memberikan penjelasan mengenai materi pelatihan dan memotivasi anggota kelompok agar memiliki ketetampilan dan keahlian di bidang pembentukan industri kecil khususnya diversifikasi produk olahan kerupuk balok;

2) Metode tanya jawab: metode tanya jawab sangat penting dapat mengukur peserta pelatihan dapat menerima penjelasan dan materi yang diberikan;

3) Metode aplikasi: metode aplikasi proses pengolahan kerupuk balok dengan 3 varian yaitu bayam, wortel dan original, dilakukan melalui praktik proses pengolahan.

Partisipasi mitra dalam pelaksanaan program ditunjukkan dengan adanya dukungan dan kesanggupan kerja sama sebagai mitra dengan tim dari Universitas Dehasen Bengkulu dalam Program Kemitraan Masyarakat. Partisipasi mitra ini ditunjukkan melalui pelaksanaan kegiatan secara bersama-sama dalam hal penyediaan bahan baku dan sampel produk, penyiapan lokasi kegiatan, pelaksanaan kegiatan uji sensoris dan penyediaan data untuk analisis.

\section{HASIL DAN PEMBAHASAN}

Indonesia sangat kaya akan tanaman pangan dengan berbagai jenis dan rasa, membentang dari ujung barat sampai ujung timur Nusantara. Berbagai tanaman pangan itu ada yang harus diolah dengan cita rasa khas dan bergizi tinggi. Banyak pula yang bisa dimakan mentah (buah-buahan dan sayuran) yang sehat menyegarkan. Kekayaan ini memberikan kontribusi potensi diversifikasi produk pangan yang cukup beragam di Indonesia. Perhatian terhadap pentingnya diversifikasi pangan dari pemerintah sebenarnya sangat tinggi. Kebijakan mengenai hal ini dapat ditemukan di berbagai dokumen, mulai dari UU Pangan, PP Ketahanan Pangan dan Gizi, Rencana Aksi Pangan dan Gizi tingkat Nasional dan Daerah (RAN-PG dan RAD-PG), Kebijakan Umum Ketahanan Pangan (KUKP), hingga Perpres 22/2009 tentang Percepatan Penganekaragaman Konsumsi Pangan Berbasis Sumberdaya Lokal (Noegroho, 2019). Hasil penelitian Suismono dan Hidayah (2011), menunjukkan bahwa berdasarkan sebarannya, produk pangan pokok di Indonesia dapat dikelompokkan menjadi 3 
golongan yaitu: untuk wilayah Indonesia Bagian Barat mengkonsumsi makanan pokok "nasi non beras", untuk wilayah Indonesia Bagian Tengah mengkonsumsi makanan pokok "bubur dari bahan tepung" dan untuk wilayah Indonesia Bagian Timur mengkonsumsi makanan pokok "bubur dari bahan pati". Lebih lanjut, Nur'aini, dkk (2017) menjelaskan hasil kegiatan pengabdian kepada masyarakat yang dilakukan pada kelompok perempuan di Desa Bukit Peninjauan II dan Desa Sidoluhur Kabupaten Seluma Bengkulu memberikan hasil yang signifikan terhadap peningkatan kapasitas baik secara softskill maupun secara ekonomi.

Kerupuk balok merupakan makanan selingan yang terbuat dari bahan yang mengandung pati (tapioka) yang diberi bumbu dan tambahan bahan lainnya. Cara membuat kerupuk yaitu dengan membuat adonan dasar basah (biang) dari tapioka hingga membentuk gel, kemudian ditambahkan seluruh bahan lalu diuleni hingga kalis dan dikukus hingga \pm 2 jam. Kerupuk dibuat dari bahan dasar tapioka dan diberi tambahan bumbu lainnya seperti bawang putih dan garam (Rohaendi, 2013). Bahan yang ditambahkan untuk meningkatkan nutrisi pada kerupuk balok berupa bayam atau wortel. Bayam dan wortel merupakan tumbuhan yang biasa ditanam untuk dikonsumsi daunnya sebagai sayuran hijau. Bayam merupakan sayuran sumber zat besi yang penting. Wortel juga mengandung vitamin B1, B2, B3, B6, B9, dan C, kalsium, magnesium, fosfor, kalium, dan sodium (Sundari, 2019). Selain karena kandungan gizi yang tinggi, bahan baku bayam dan wortel mudah di dapat serta harganya terjangkau oleh mitra untuk dijadikan varian rasa "kerupuk balok".

Demi meningkatkan kualitas dan daya saing produk kerupuk balok hasil produksi Kelompok Usaha Maju dan Kelompok Raos Echo, tim pengabdi memberikan pelatihan diversifikasi produk olahan kerupuk balok. Perbaikan teknologi pengolahan kerupuk balok dengan melakukan diversifikasi varian rasa yaitu kerupuk balok bayam, kerupuk balok wortel dan kerupuk balok original. Teknologi pengolahan kerupuk balok yang akan ditransfer kepada mitra, dengan rincian sebagai berikut:

Bahan

a. Bayam atau wortel 250 gram

b. Telur 2 butir

c. Tepung tapioka 500 gram

d. Garam 1 sendok makan

e. Bawang putih 20 gram

f. Minyak goreng 1 Liter

g. Plastik kemas

Alat

a. Pisau

b. Blender

c. Panci pengukus

d. Alat cetak ampia

e. Cabinet dryer (pengering kabinet)

f. Penggorengan

g. Peniris minyak/spinner

h. Sealer 
Proses Pengolahan

a. Untuk kerupuk bayam, bahan bayam dicuci bersih kemudian diblender. Untuk kerupuk wortel, bahan wortel dikupas, dicuci dan dikukus sampai matang (lunak), Kemudian dihancurkan menggunakan blender sampai halus.

b. Bahan baku yang sudah dihancurkan dicampurkan dengan tepung tapioka dan bumbu sampai merata.

c. Adonan kemudian dicetak dengan menggunakan ampia sampai berbentuk balok.

d. Adonan yang dicetak kemudian disusun di papan penjemur, lalu dikeringkan dengan menggunakan kabinet dryer hingga kering sempurna (berwarna kuning).

e. Kemudian minyak goreng dipanaskan pada api sedang dan digoreng sampai mengembang dan berwarna kuning kecoklatan.

f. Kemudian minyak goreng dipanaskan pada api sedang dan digoreng sampai mengembang dan berwarna kuning kecoklatan.

g. Setelah dingin dikemas dalam plastik.

Pelaksanaan penyuluhan dilakukan secara terpisah antara Kelompok Usaha Maju. Respon dan antusiasme anggota kelompok sangat tinggi, terlihat dari kegiatan penyuluhan yang dihadiri oleh seluruh anggota kelompok. Dokumentasi kegiatan sosialisasi dan diklat ditampilkan pada Gambar 2.

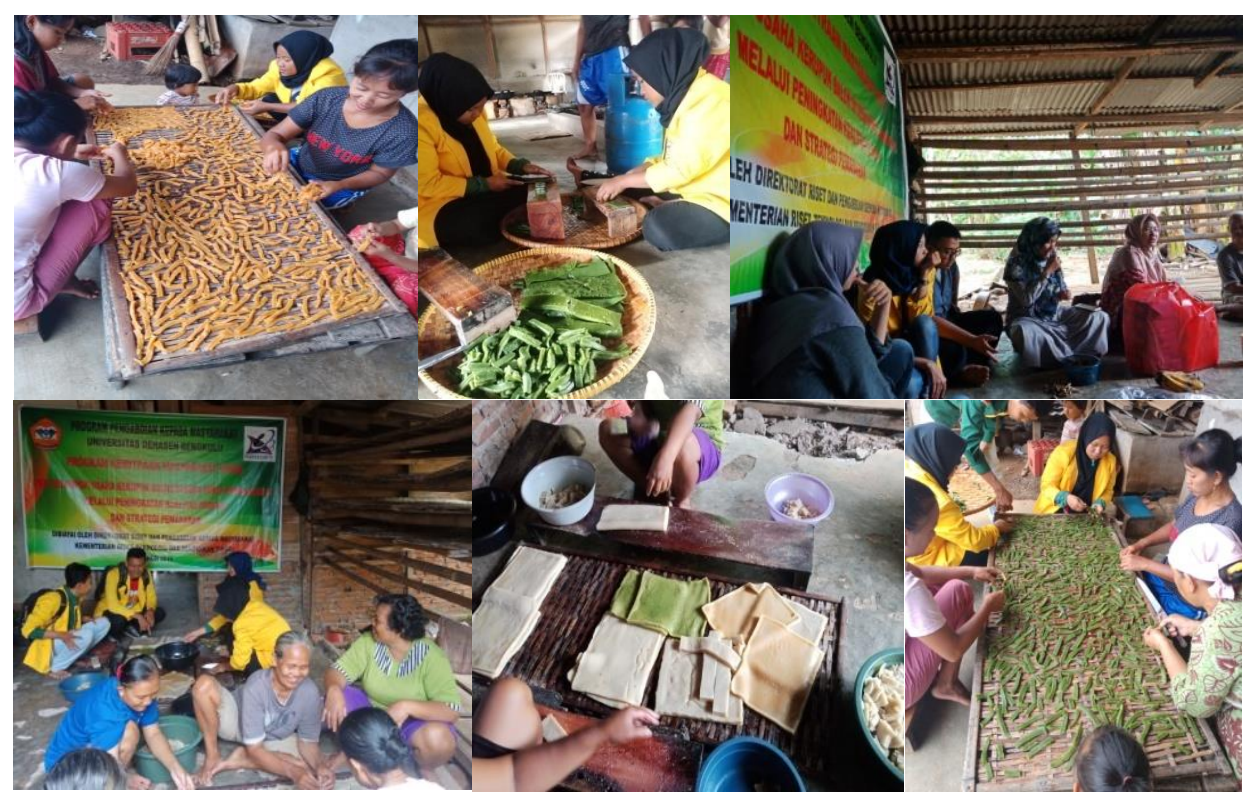

Gambar 2. Kegiatan Sosialisasi dan Diklat di Kelompok Usaha Maju dan Kelompok Raos Echo

Kegiatan sosialisasi melibatkan mahasiswa (pembagian tugas seperti pada Tabel 1) sebagai pelaksana praktik pengolahan, meliputi proses pengolahan kerupuk balok bayam, kerupuk balok wortel dan kerupuk balok original, dengan penjelasan sebagaimana tertuang pada Tabel 1. 
Tabel 1. Pembagian Tugas Kegiatan Sosialisasi dan Diklat Teknologi Pengolahan

\begin{tabular}{|c|c|c|c|}
\hline $\begin{array}{l}\text { Nama } \\
\text { Kelompok }\end{array}$ & Koordinator Pelaksana & Nama Mahasiswa & $\begin{array}{l}\text { Jumlah Anggota } \\
\text { Kelompok Hadir }\end{array}$ \\
\hline Raos Echo & Evi Andriani, SP.,M.Si & $\begin{array}{l}\text { Yuni Lestari } \\
\text { Wahyudi } \\
\text { Salu Zerwina }\end{array}$ & 6 orang \\
\hline Usaha Maju & Dewi Suranti, M.Kom & $\begin{array}{l}\text { Edi Saputra } \\
\text { Novi Sartika } \\
\text { Panggi Oktara } \\
\text { Anggiat Faisal }\end{array}$ & 8 orang \\
\hline
\end{tabular}

\section{Perancangan Desain Kemasan dan Pelabelan Produk Kerupuk Balok}

Tujuan utama pengemasan untuk produk pangan, sebagai pelindung yang optimal untuk melindungi produk dari penyebabkerusakan dari luar seperti cahaya, oksigen, kelembaban, mikroba atau serangga dan juga untuk mempertahankan mutu dan nilai gizi serta memperpanjang umur simpan. Pertimbangan lainnya adalah: pengemasan harus didesain dengan bentuk dan ukuran yang cocok dan desain grafisnya harus mampu menarik pembeli. Disisi lain, perkembangan teknologi pengemasan sangatlah pesat. Kemasan tidak hanya dituntut untuk memenuhi fungsi-fungsi dasar sebagai wadah, perlindungan dan pengawetan, media komunikasi, serta kemudahan dalam penggunaannya (Sucipto dkk, 2017). Berdasarkan kesepakatan antara mitra kelompok industri kerupuk balok dan tim pengabdi, perbaikan desain kemasan dan labeling sangat perlu dilakukan. Kegiatan perancangan desain kemasan dilakukan dengan dua tahap, yaitu tahap perancangan desain label kemasan dan jenis kemasan. Perancangan desain label kemasan terdiri dari dua jenis, yaitu menggunakan teknik sablon dan teknik printing. Diklat teknik sablon dilaksanakan dengan mengundang narasumber ahli sablon berikut pemberian seperangkat peralatan sablon yang dibutuhkan oleh kedua mitra. dokumentasi kegiatan diklat dan tampilan desain kemasan kerupuk balok untuk kedua mitra disajikan pada Gambar 3 dan Gambar 4.

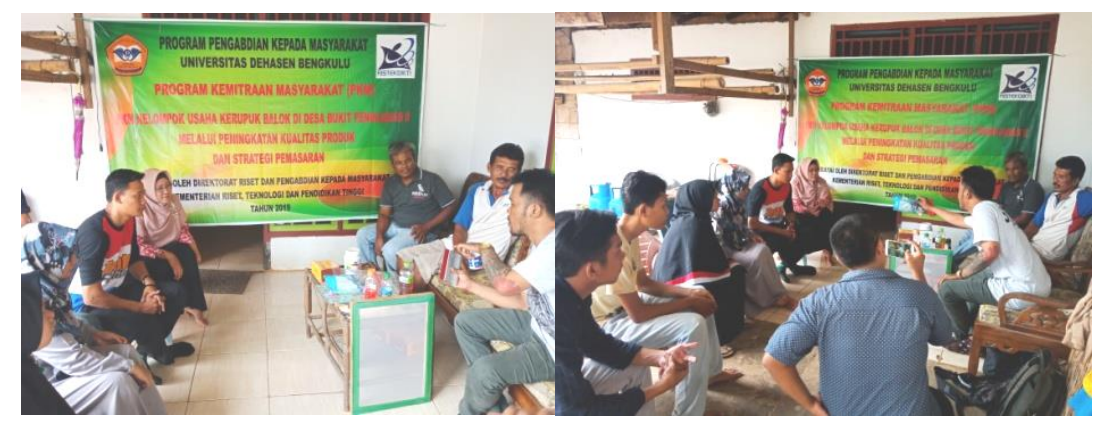

Gambar 3. Dokumentasi Kegiatan Diklat Perencanaan Desain Kemasan 


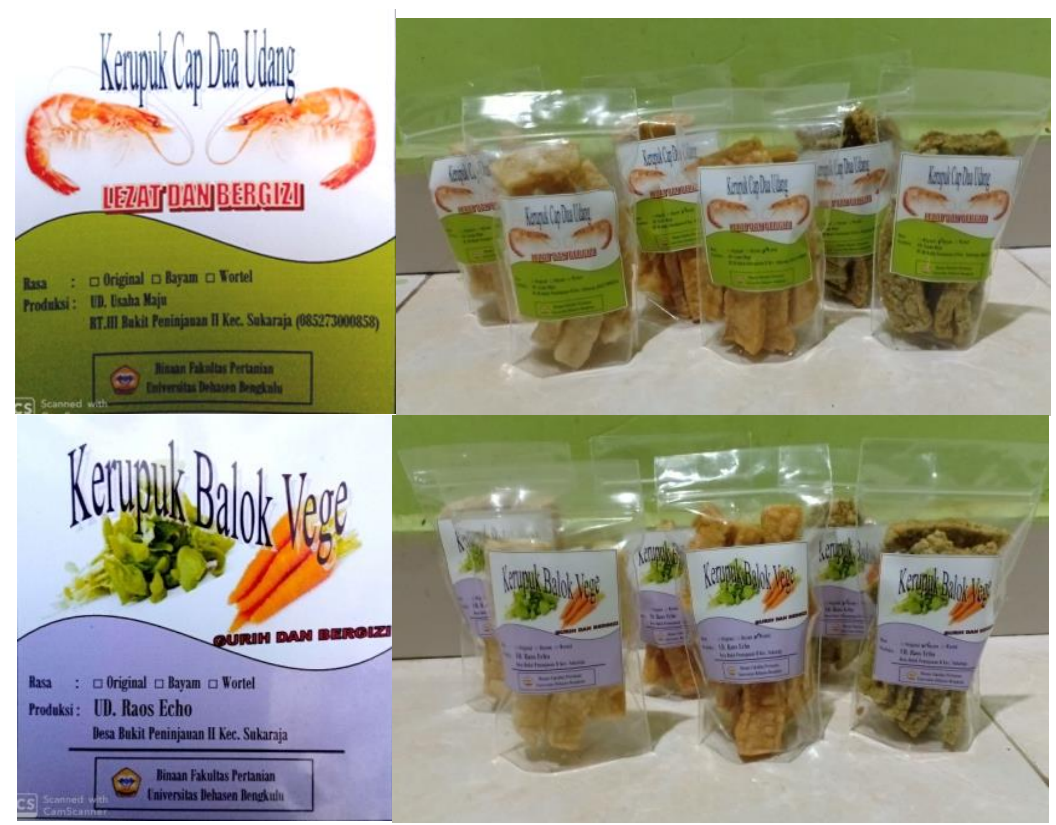

Gambar 4. Tampilan Desain Kemasan Kerupuk Balok Kelompok Usaha Maju dan Raos Echo

\section{Pemberian Bantuan Peralatan Produksi dan Sarana Usaha}

Salah satu permasalahan utama yang dihadapi oleh mitra adalah, terkendalanya proses pengeringan pada saat hujan. Menurut Riansyah dkk (2013), pengeringan adalah suatu metode untuk mengeluarkan atau menghilangkan sebagian air dari suatu bahan dengan cara menguapkan air tersebut dengan menggunakan energi panas. Secara umum keuntungan dari pengawetan ini adalah bahan menjadi awet dengan volume bahan menjadi kecil sehingga memudahkan dalam pengangkutan. Tujuan dari pengeringan adalah mengurangi kadar air bahan sampai batas dimana mikroorganisme dan kegiatan enzim yang dapat menyebabkan pembusukan akan terhenti, dengan demikian bahan yang dikeringkan dapat mempunyai waktu simpan yang lama. Proses pengeringan kerupuk balok yang selama ini dilakukan oleh kelompok Usaha Maju dan Raos Echo, adalah dengan cara penjemuran di atas para-para dan hanya bergantung pada sinar matahari. Dengan metode semacam itu, pengeringan membutuhkan waktu $4-5$ hari. Berdasarkan pengalaman yang disampaikan oleh kedua mitra, sering terjadi kegagalan proses yang disebabkan oleh turunnya hujan pada hari kedua atau ketiga saat pengeringan. Kegagalan proses ini menyebabkan kerugian yang cukup fatal, karena kerupuk yang tidak kering sempurna menjadi mudah ditumbuhi jamur sehingga harus dibuang atau dijadikan makanan ternak. Untuk mengatasi permasalahan tersebut, tim pengabdi memberikan bantuan mesin pengering kabinet, yang bisa menjadi alternatif solusi, jika musim hujan berlangsung. Selain mesin kabiner drier, tim pengabdi juga memberikan bantuan peralatan antara lain:
1) Kebinet drier
2) Peralatan sablon
3) Tabung Gas LPJ
4) Selang gas
5) Bahan kemasan 
6) Toples

7) Baskom

8) Kuali

9) Pisau

Pemberian bantuan mesin dan peralatan tersebut disertai dengan sosialisasi cara penggunaannya, seperti ditampilkan pada Gambar 5 dan Gambar 6.

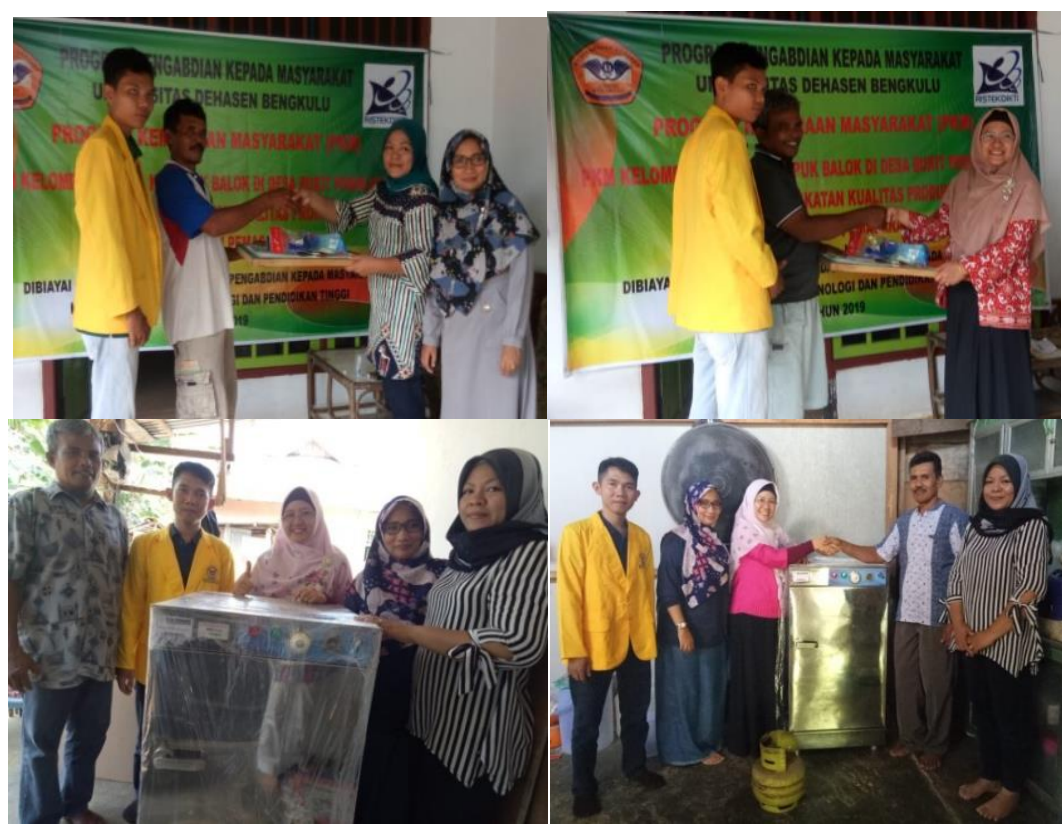

Gambar 5. Penyerahan Bantuan Peralatan Produksi

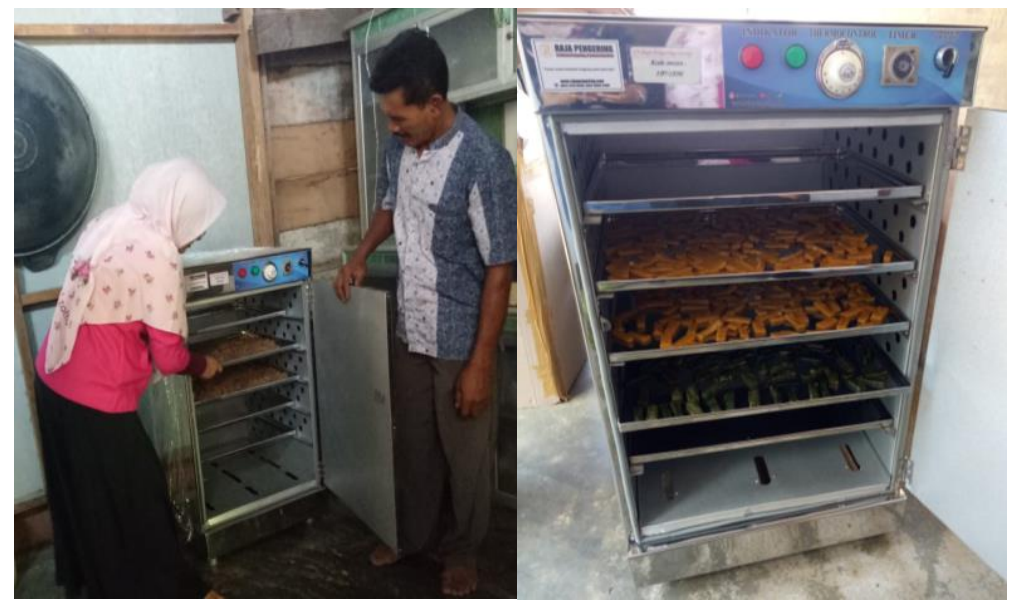

Gambar 6. Sosialisasi Penggunaan Mesin Kabinet Drier

\section{Diklat Sistem Manajemen Keuangan dan Strategi Pemasaran}

Manajemen keuangan adalah suatu kegiatan perencanaan, penganggaran, pemeriksaan, pengelolaan, pengendalian, pencarian dan penyimpanan dana yang dimiliki oleh suatu organisasi atau perusahaan (Sudana, 2019). Sistem manajemen 
keuangan dan strategi pemasaran yang baik dalam sebuah industri sangat menentukan keberhasilan dan keberlanjutan usaha. Oleh karena itu, tim bersama-sama mitra sepakat untuk melakukan perancangan sistem manajemen keuangan dan strategi pemasaran dalam usaha yang sedang dikembangkan, dengan tahapan kegiatan sebagai berikut:

1) Tim bekerja sama dengan tenaga ahli di bidang manajemen keuangan untuk merancang sistem manajemen keuangan yang cocok bagi Kelompok Usaha Maju dan Raos Echo. Tenaga ahli yang ditunjuk adalah salah satu dosen pada Fakultas Ekonomi Universitas Dehasen dengan bidang keahlian akuntansi, yaitu Neri Susanti, SE.,M.Si.

2) Dilakukan simulasi dan latihan pelaporan keuangan kegiatan usaha untuk masingmasing kelompok.

Antusiasme peserta diklat sangat tinggi, yang ditunjukkan pada Gambar 7.

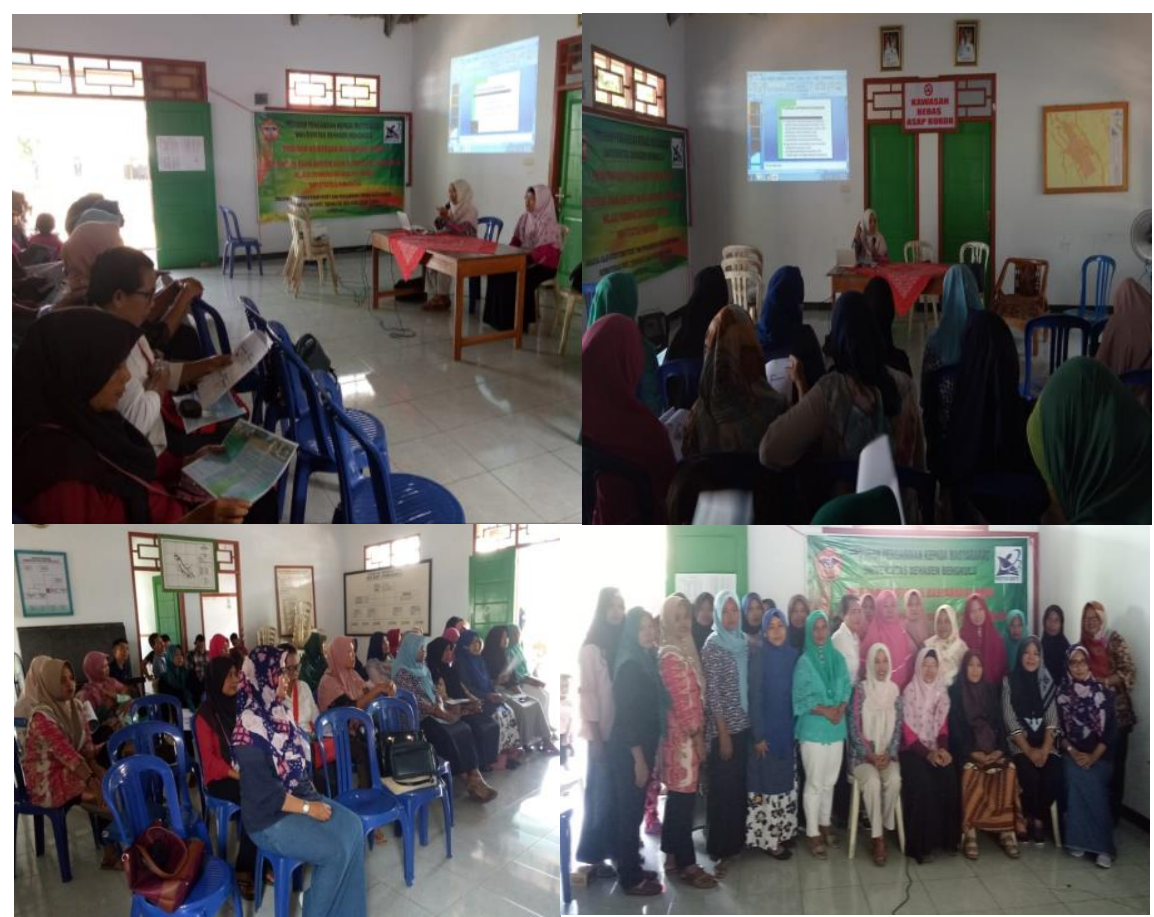

Gambar 7. Kegiatan Diklat Manajemen Keuangan Industri Kecil

\section{SIMPULAN}

Kegiatan pengabdian kepada masyarakat ini memperoleh beberapa kesimpulan, yaitu: 1) Telah dilakukan peningkatan kapasitas produk Kelompok Usaha Maju dan Kelompok Raos Echo dalam pengolahan kerupuk balok, melalui penambahan varian baru, yaitu kerupuk bayam dan kerupuk wortel; 2) Bertambahnya pengetahuan dan keterampilan anggota Kelompok Usaha Maju dan Kelompok Raos Echo dalam desain label dan kemasan produk, yang ditunjukkan dengan telah terbentuknya desain kemasan dan label untuk produk yang dihasilkan; 3) Meningkatnya sistem pengeringan dalam pengolahan kerupuk balok pada Kelompok Usaha Maju dan Kelompok Raos Echo, melalui penambahan alat pengering kabinet; dan 4) Meningkatnya pengetahuan dan kemampuan anggota Kelompok Usaha Maju dan Kelompok Raos Echo tentang manajemen keuangan dan strategi pemasaran yang baik. 


\section{REFERENSI}

Dinas Kesehatan Depok. (2017). Sertifikasi produksi pangan industri rumah tangga. Retrieved July 28, 2017 from http://dinkes.depok.go.id/sipkap/2015/06/22/sertifikasi-produksipangan-industri-rumah-tangga

Noegroho, A,. (2019). Diversifikasi pangan berbasis lokal. Retrieved July 07, 2019 from https://www.beritasatu.com/opini/6314-diversifikasi-pangan-berbasis-lokal.html.

Nur'aini, H., Widawati, L., \& Suranti, D. (2017). Pemberdayaan kelompok perempuan melalui peningkatan produk lokal di Kecamatan Sukaraja Kabupaten Seluma Provinsi Bengkulu. Dharma Raflesia, 15(2), 95-103.

Rahmana, A., Iriani, Y., \& Oktarina, R. (2012). Strategi pengembangan usaha kecil menengah sektor industri pengolahan. Bandung: Universitas Widyatama.

Riansyah, A., Supriadi, A., \& Nopianti, R. (2013). Pengaruh perbedaan suhu dan waktu pengeringan terhadap karakteristik ikan asin sepat siam (Trichogaster pectoralis) dengan menggunakan oven. Jurnal Fishtech, 2(1), 53-68.

Rohaendi, D. (2013). Memproduksi kerupuk sangrai. Jakarta: Gramedia Pustaka Utama.

Sucipto, N., Suriasih, K., \& Kencana, P. K. D. (2017). Pengemasan pangan, kajian pengemasan yang aman, nyaman, efektif dan efisien. Denpasar: Udayana University Press.

Sudana, I. M. (2019). Manajemen keuangan teori dan praktik. Surabaya: Airlangga University Press.

Suismono., \& Hidayah, N. (2011). Pengembangan diversifikasi pangan pokok lokal. Jurnal Pangan, 20(3), 295-314.

Sundari, S. (2019). Analisis perbandingan antara pupuk organik urin kelinci dengan pupuk non-organik (npk mutiara) terhadap pendapatan dan hasil panen wortel di Desa Hanakau Kabupaten Lampung Barat. Industrika, 3(1), 24-35. 